National Technical University of Oil and Gas. Series "Economics and Management in the Oil and Gas Industry", 1(9), 47-55 [ in Ukrainian].

6. K. V. Pavlov, I. L. Shevchuk. (2018). Innovatsiini finansovo-kredytni vazheli yak skladova efektyvnoi antymonopolnoi polityky [Innovative financial leverage as part of an effective antitrust policy]. Naukovyi visnyk Uzhhorodskoho universytetu-Uzhgorod University Scientific Bulletin, 51, 72-74. [in Ukrainian].

7. I. M. Strishenets, O. V. Novosad (2017). Osoblyvosti funtsionuvannia innovatsiy v diialnosti hazorozpodilnykh pidpryiemstv [Features of functioning of innovations in activity of gas-distributing enterprises]. Aktualni problemy upravlinnia sotsialno-ekonomichnymy systemamy- Actual problems of management of socioeconomic systems. Proceedings from: International Scientific and Practical Conference, 1(9), (pp. 162-163). Lutsk: RVV Lutskoho NTU [in Ukrainian].

8. Finansovi rezultaty 2016 roku PAT «Volynhaz» [Financial Results of 2016 Volyngaz PJSC]. Retrieved from https://vl.104.ua/ua/files/22590/1 [in Ukrainian].

9. Zakon Ukrainy "Pro zakhody shchodo realizatsii derzhavnoi polityky u sferi pryrodnykh monopolii" pryiniatyi 16 hrudnia 1996 roku №853/97 [Law of Ukraine on measures to implement state policy in the field of natural monopolies from December 161996 №853/97. Retrieved from https://zakon.rada.gov.ua/laws/show/853 / 97 [in Ukrainian].

Стаття надійшла до редакції 28.06.2019 р.

УДК: 338.2

Павлова Олена,

доктор економічних наук, професор,

Східносвропейський національний університет імені Лесі Українки, завідувач кафедри аналітичної економіки та природокористування, м. Луцьк; ORCID ID: 0000-0002-8696-5641 e-mail: pavlova.olena@eenu.edu.ua

Павлов Костянтин, доктор економічних наук, доцент, Східноєвропейський національний університет імені Лесі Українки, кафедра аналітичної економіки та природокористування, м. Луцьк; ORCID ID: 0000-0003-2583-9593 e-mail: pavlovkv@icloud.com

Купчак Володимир, доктор економічних наук, доцент, Східноєвропейський національний університет імені Лесі Українки, кафедра аналітичної економіки та природокористування, м. Луцьк; e-mail: kupchak@me.com

Червеняк Вікторія, студентка,

Східноєвропейського національного університету імені Лесі Українки, кафедра аналітичної економіки та природокористування м. Луцьк

https://doi.org/10.29038/2411-4014-2019-03-105-112

\title{
ФУНКЦІОНУВАННЯ МЕРЕЖІ ПІДЗЕМНИХ ГАЗОВИХ СХОВИЩ В КОНТЕКСТІ ЕНЕРГЕТИЧНОЇ БЕЗПЕКИ КРАЇНИ
}

В даній статті було досліджено особливості функціонування підземної мережі газових сховищ України в контексті енергетичної безпеки. Окреслено організаційно-економічний базис енергетичної безпеки держави на 
тлі функціонування мережі газових сховищ держави. Здійснено огляд теоретичних підходів до розуміння поняття «енергетична безпека» та шляхом систематизації широкого спектра понять дано уніфіковане визначення даного поняття. Здійснено огляд теорії практики функціонування мережі газових підземних сховищ, які є важливим елементом у забезпеченні енергетичної безпеки країн Європи, а також у формуванні сприятливого транзитного потенціалу. Використовуючи системний підхід, аналіз низин законотворчих документів, а також історію становлення резервуарів сховищ газу, вдалося дійти висновку що вони можуть стати невід'ємними компонентами в мережевій взаємодії між канали постачання та зберігання газу в геополітичному просторі в напрямі до реформування до лібералізованого ринку газу. Беручи до уваги, географічну спорідненість та здебільшого скупчення необхідних мережевих газових ресурсів та в результаті емпіричного аналізу вдалося простежити енергетичну залежність багатьох країн Європи від газового резервного балансу нашої країни. Оригінальність дослідження полягає в обгрунтуванні теоретичних гіпотез відносно основних чинників та тенденцій геополітичної політики адаптування просторових мереж постачання та зберігання газових ресурсів в контексті лібералізованого газового ринку.

Ключові слова: мережа газових ресурсів, енергетична безпека, лібералізований ринок, реформування, енергетична незалежність, підземні сховища, газове сховище.

Павлова Елена,

доктор экономических наук, профессор,

Восточноевропейский национальный университет имени Леси Украинки, заведующий кафедрой аналитической экономики и природопользования, г. Луцк

Павлов Константин, доктор экономических наук, доцент, Восточноевропейский национальный университет имени Леси Украинки, кафедра аналитической экономики и природопользования, г. Луцк

Купчак Владимир, доктор экономических наук, доцент, Восточноевропейский национальный университет имени Леси Украинки, кафедра аналитической экономики и природопользования, г. Луцк

Червеняк Виктория, студентка,

Восточно-Европейского национального университета имени Леси Украинки, кафедра аналитической экономики и экологических наук, г. Луцк

\section{ФУНКЦИОНИРОВАНИЯ СЕТИ ПОДЗЕМНЫХ ГАЗОВЫХ ХРАНИЛИЩ В КОНТЕКСТЕ ЭНЕРГЕТИЧЕСКОЙ БЕЗОПАСНОСТИ СТРАНЫ}

В этой статье были исследованы особенности функционирования подземной сети газовых хранилищ Украины в контексте энергетической безопасности. Изложена организационно-экономическая основа энергетической безопасности государства против функционирования сети газовых хранилищ государства. В ходе обзора теоретических подходов к пониманию понятия "энергетическая безопасность" и систематизации широкого спектра концепций дается единое определение этой концепции. Обзор теории эксплуатации газоподземных хранилищ, которая является важным элементом обеспечения энергетической безопасности европейских стран, а также формирования благоприятного транзитного потенциала. Используя системный подход, анализ низовых законодательных документов, а также историю формирования резервуаров для хранения газа был сделан вывод о том, что они могут стать неотъемлемыми компонентами в сетевом взаимодействии между каналами поставок и хранения газа в геополитическом пространстве в сторону реформирования либерализованного газового рынка. Тогда как географическое сродство и в основном накопление необходимых сетевых газовых ресурсов и в результате эмпирического анализа удалось отследить энергетическую зависимость многих стран Европы от баланса запасов газа нашей страны. Оригинальность исследования заключается в обоснованности теоретических гипотез относительно основных факторов и тенденций геополитической политики адаптации пространственных сетей поставок и хранения газовых ресурсов в контексте либерализованного газового рынка.

Ключевые слова: Сеть газовых ресурсов, энергетическая безопасность, либерализованный рынок, реформирование, энергетическая независимость, подземные хранилища, хранилища газа. 


\title{
Pavlova Olena, \\ Doctor of Economic Sciences, Full Professor, \\ Lesya Ukrainka Eastern European National University, \\ Head of the Chair of Analytical Economics and Natural Resources Management, Lutsk
}

\author{
Pavlov Kostiantyn, \\ Doctor of Economic Sciences, Assistant Professor, \\ Lesya Ukrainka Eastern European National University, \\ Chair of Analytical Economics and Natural Resources Management, Lutsk
}

Kupchak Volodymyr,

Doctor of Economic Sciences, Assistant Professor,

Lesya Ukrainka Eastern European National University,

Chair of Analytical Economics and Natural Resources Management, Lutsk

Cherenyak Victoria, Student,

Analytical Economics and environmental Sciences of Lesya Ukrainka East European National University, Lutsk

\section{FUNCTIONING OF THE NETWORK OF UNDERGROUND GAS STORAGES IN THE CONTEXT OF THE COUNTRY'S ENERGY SECURITY}

In this article the peculiarities of functioning of the underground network of gas storages of Ukraine in the context of energy security were investigated. The organizational and economic basis of energy security of the State against the functioning of the network of gas storages of the state is outlined. A review of the theoretical approaches to understanding the concept of "energy security" and by systematization a wide range of concepts is given unified definition of this concept. A review of the theory of Practice of operation of gas underground storage facilities, which is an important element in ensuring energy security of European countries, as well as the formation of favourable transit potential. Using a systematic approach, analysis of the grassroots of legislative documents, as well as the history of the formation of gas storage tanks, was concluded that they can become integral components in the network interaction between supply and storage channels Of gas in the geopolitical space towards reforming the liberalized gas market. Whereas geographical affinity and mostly accumulation of necessary network gas resources and as a result of empirical analysis it was possible to trace energy dependence of many countries of Europe from the gas reserve balance of our country. Originality of the research is the substantiation of theoretical hypotheses concerning the main factors and tendencies of geopolitical policy of adapting the spatial networks of supply and storage of gas resources in the context of the liberalized gas market. To implement the gas reform and equality of Ukraine in the European gas market, reforms should be implemented in the interests of Ukrainian citizens, providing high-quality and reliable services, while harmonizing the competitive environment between owners of Efficient gas companies. Due to the adoption of the Law on the natural gas market in 2015, the legal plane of Ukraine significantly drew closer to the EU energy legislation. At the end of the reform, it is early to say, as there are important steps ahead to create a transparent environment of an independent regulator that avoids monopoly pressure in the gas market, limit political-oligarchic lobbying and Boost investment in the specified sector. One of the most important aspects of the effectiveness of the marked steps is the significant transit potential of Ukraine, which is in a certain way based on the presence of significant reserves of underground storage of gas storages, which in turn raise national independence and Security of our country. The purpose of the publication is to light the theoretical and practical knowledge about the underground gas storages of Ukraine with the finding out of their role and importance in the energy security of the geopolitical space. The main tasks, which reveal the meaning of the specified purpose, should be noted: the historical ages of the network of gas storages; Concentration and peculiarities of gas storages functioning in Ukraine; Interaction and mutual consistency of gas tanks with European gas channels; Problematic issues that hinder the uninterrupted and safe gas supply; Place and function of the gas storage network in the context of national and European security.

Key words: Network of gas resources, energy security, liberalized market, reforming, energy independence, underground storages, gas storage. 
Постановка проблеми. Задля реалізації газової реформи та рівноправності України на європейському газовому ринку здійснені реформи мають бути в інтересах громадян України, забезпечуючи якісні та надійні послуги, водночас гармонізувати конкурентне середовище між власниками ефективних газових компаній. За рахунок прийняття в дію Закону «Про ринок природного газу» у 2015 році, правова площина України суттєво наблизилася до енергетичного законодавства ЄС. На разі, про завершення реформ говорити рано, оскільки попереду залишаються важливі кроки для створення прозорих умов роботи незалежного регулятора, який дозволить уникнути монопольного тиску на газовому ринку, обмежить політично-олігархічне лобіювання та стимулюватиме приріст інвестицій в зазначену сферу.

Одним із вагомих аспектів ефективності налічених кроків є значний транзитний потенціал України, який певним чином сформований виходячи 3 наявності значних резервів підземного зберігання газових сховищ, які в свою чергу підвищують національну незалежність та безпеку нашої країни.

Аналіз досліджень цієї проблеми. Широкий діапазон зазначених питань газових сховищ в контексті національного та регіонального потенціалу нашої країни висвітлено вітчизняними вченими, зокрема С. Галянтом, О. Гарматюк, О. Дзьобою, Н. Лінчевською, М. Коротьою. Проблемами неефективності використання підземної мережі газових сховищ займалися С. Бобрівець, І. Бойко, М. Данилюк, К. Павлов, О. Павлова. Однак, попри значний науковий доробок, існує низка питань 3 різних сторін зазначеної проблемами, які потребують майбутніх грунтових досліджень; зокрема особливостей структури, стану та призначення мережі підземних газових сховищ.

Мета публікації. Висвітлення теоретичних та практичних знань про підземні газові сховища України з з'ясуванням їх ролі та значення в енергетичній безпеці геополітичного простору.

До основних завдань, які розкривають зміст зазначеної мети, варто відмітити: історичні віхи становлення мережі газових сховищ; зосередження та особливості функціонування газових сховищ України; взаємодію та взаємо узгодженість резервуарів газу з європейськими газовими каналами; проблемні питання, які гальмують безперебійне та безпечне газопостачання; місце та функції мережі газових сховищ в контексті національної та європейської безпеки.

Виклад основного матеріалу. Починаючи з 1965 року Україна активно впроваджувала в дію побудову підземних сховищ. Спочатку задля забезпечення основних регіональних центрів газовими ресурсами, згодом 3 метою формування мережевих комплексів резерву газу для транзитної та накопичувальною функцій, як необхідної умови енергетичної безпеки країни. На разі підземні сховища вміщують об'єм рівний - 31,95 млрд м.куб. газу та посідає другу позицію в Європі, поступаючись Росії, але має першість за критерієм добової продуктивності відносно резервного заповнення 250 млн. м.куб. 3 огляду на існування немалої кількості нормативно-правового базису функціонування підземних газових сховищ було сформовано цілісну концепцію для модернізації ГТС України, як єдиної системи газопостачання та підземного зберігання газу на перспективу.

Основною місією існуючої концепції є ретроспективний аналіз нерівномірності споживацьких об'ємів, можливості їх регулювання та вироблення стратегічних завдань для управління та подальшого розвитку системи газопостачання. Близько 80\% газових сховищ України зосереджується у Західній частині країни, поруч з СС та $\epsilon$ пересічними до найбільших та найважливіших потоків Росії, що без сумніву підвищує енергетичну незалежність нашої країни [6]. Беручи до уваги, що промислові об'єкти, які зосереджені у східній та південно-східній частині України є в основному основними суб'єктами споживання, ймовірність збільшення об'ємів резервування мережі підземних сховищ газу Донецького та Причорноморського комплексів вирішило би проблему переведення сховищ газу Західного регіону для постачання зовнішнім споживачам на транзитній основі. Історична довідка свідчить, що відлік у видобуванні українських газових ресурсів варто рахувати 3 1924 року під час будівництва перших в Україні газопроводів Дашава-Старий-Дрогобич та ДашаваЛьвів. Через два десятки роки відбулось інтенсивне спорудження магістральних газопроводів. Наявність існуючих підземних сховищ дає нашій країні можливість мати одну 3 найбільших газотранспортних систем в Європі.

Відповідно до показників ПАТ «Укртрансгаз», до складу газотранспортної системи відносяться газопроводи протилежністю - 38,6 тис.км, на вході пропускна здатність - 285,7 млрд. м.куб. на рік, 
на виході - 178 млрд. м.куб. на рік, водночас на країни Європи припадає - 146 млрд м.куб. на рік, 72 компресорні станції сумарної протяжності - 262 5442,9 MB, а також 12 мережевих підземних сховищ газових ресурсів загальних об’ємом - 31 млрд. м.куб [9].

Сприятливими умовами задля розширення мереж по газифікацій служить робота теплових електростанцій, металургія, машинобудування, харчова промисловість, промисловості будівельних матеріалів, хімічна галузь. Окрім того, газотранспортна система України транзитує $70 \%$ експорту російського газу забезпечуючи четвертину потреби європейських країн. Щорічно, близько 100 млрд. м.куб. газу експлуатує нашу газотранспортну систему шляхом транзиту до 18 країн Центральної, Західної та Південної Європи. Україна вважається одним із найбільших споживачів газових ресурсів, що безперечно $\epsilon$ наслідком величезних запасів газу. Якщо брати до уваги віки становлення газотранспортної системи, то вона виконувала ще й дотичну роль по газодобуванню. Таким чином, забезпечуючи газом внутрішніх та зовнішніх споживачів Росії, Молдови, Білорусі, Литви, Латвії, Польщі та Чехословаччини. В результаті відкрилися та ввелися в експлуатацію родовища на Сході України (Дніпро-Донецька западина), на півдні Росії (Красновський та Ставропольські краї), південному (Оренбузька область) та частина в Західному Сибірі. В той же час, безпечне газопостачання вимагало модернізації та розширення трубопровідної сітки, яка щороку збільшувалася охоплюючи все нові та віддалені відводи. Зрештою формування та будівництво підземних мережевих сховищ стало необхідним та ефективним шляхом реформування національних газових ринків. Тому 80-90 роки минулого століття стали вихідними для остаточного виникнення та технічного оснащення підземних сховищ газу. Зростання частини резерву газових ресурсів вимагало проведенню бурівельних робіт та експлуатації понад 1160 капітально-видобувних свердловин та цехів по компресуванню загальною потужністю близько $355 \mathrm{MBT}$, що дозволило б збільшити активну місткість підземних сховищ на 19 млрд м.куб. [6,8]. В той же час, європейський досвід свідчить, що перші створені підземні сховища на газовому джерелі проводилися в 1954 році в м. Ясло, Польща. Згодом, в інших країнах Європи розпочався інтенсивний процес розвитку підземних сховищ газу в основному біля великих осередків газопостачання та на базі водоносних структур. В результаті об'єм газу для провідних країн Європи в 1966 році зберігався в пластах, які в 1,5 рази перевищували проекти і в сезони відбирання, та вдалося відібрати 50\% проектного активного газу.

Водночас підземні мережеві сховища $є$ частиною структури газотранспортної системи, які в своїй сукупності створюють потужну систему підземного резерву по зберіганню газу, вирішуючи водночас ряд важливих питань, серед яких: вплив на неоднорідність газопостачання; цінове компенсування газопостачання шляхом сезонної нерівномірності; регулювання подачі газу в несприятливу погоду через резервування його у підземних сховищах; формування газобезпечного безпечного середовища на випадок аварійних та форс мажорних ситуацій на газопроводах; дотримання умов надійності при транзитній та експертній ролі сховищ.

3 точки зору зовнішніх чинників сприяння формування мережі підземних сховищ газу, то варто відмітити деякі обставини, зокрема: унікальність географічного розташування для резервування запасів газу континентального значення; наявність достатньої та ємної місткості підземних резервуарів газових та нафтових родовищ (якісні геолого-фізичні параметри висока гармонічність поверхнева глибина залягання продуктивних пластів); геологічне сприятливе транзитне розташування України; теоретичний та граничний досвід резервування та зберігання газових ресурсів для Польщі, Угорщини, Югославії. Останніми роками в підземних сховищах України закачується від 14 до 16 млрд м.куб. за сезон. Тому, енергетична безпека країн Європи на пряму є залежною від наявності та функціонування підземних сховищ природного газу України.

Разом $з$ тим газотранспортна система України з'єднується 3 аналогічними мережами межуючих транскордонних країн: Росії, Білорусі, Польщі, Словаччини, Угорщини, Румунії, Молдови, та інтегрується в загальноєвропейську газову мережу.

Стосовно структури мережевих газових сховищ, то найбільше 3 них є Західне підземне зберігання газу (ЗПЗГ) створене у Прикарпатському регіоні в системі трансконтинентальних міждержавних і внтрішньодержавних газопроводів та складається в свою чергу 35 мережевих резервуарів: Більче-Волинське-Угерське, Угерське, Отарське, Дашавське, Богородчанське. Між зазначеними газосховищами існує взаємна система газопроводів, що створює передумови для розподілу потоків газу, задля задоволення потреб місцевих та віддалених споживачів. Окрім того, $\epsilon$ 
можливість нагромаджувати в них необхідний резервний об'єм задля вирішення стратегічних та оперативних завдань. Загалом, даний комплекс вирішує більше $80 \%$ усіх газових резервів України. Другим по об'єму комплексом підземних сховищ є Центральний ЗПЗГ, який включає в себе Олишківське, Червонопартизанське, Солохівське та Кегичівське газосховища, створений в Київській системі магістральних газопроводів та призначений задля надійності газопостачання споживачів столиці, а також Київської, Хмельницької, Вінницької, Житомирської, Кіровоградської, Черкаської, Чернігівської, Полтавської, Сумської та Харківської областей [10].

Активний об'єм газу в межах комплексу становить близько $12 \%$ від загального обсягу газу у газосховищах країни.

Ще одним комплексом, який на разі перебуває на тимчасово окупованій території є Східний ЗПЗГ створений у Донецькій та Луганських областях. Активний об'єм газу в межах комплексу становить більше 20\% відносно існуючих газових резервів. В Придніпровському районі охоплює Південний ЗПЗГ, який включає два напрямки: Пролетарське та Глібовське газосховища. Основна місія газового сховища полягає не лишень у забезпеченні внутрішнього споживання, але й транзитних поставок газових ресурсів через південні регіони України в Молдову, та в країни Балканського півострова, а також в Туреччину. Величина газових резервів є відносно не великою та становить - 5\% усієї частини резервованого газу. Особливістю будь-якого ПСГ України є відстань від 3 до 3,5 тис.км. від основних осередків видобування природного газу, а також наявність сприятливих геологічних умов, що дозволяє підвищувати не лишень внутрішню але й зовнішню конкурентоспроможність вітчизняного газу. Окрім того, наявність підземних сховищ $є$ неодмінною умовою відтворення господарського кругообігу на ринкових засадах, маніпулювання потоками, щороку альтернативність використання газових ресурсів, оперативну стратегічність резервування, особливо в Західному регіоні [4].

Загалом, резерв активних потужностей газу оцінюється близько 15 млрд м.куб. в українських підземних сховищах, що підтверджує транзитну та резервну вигоду для іноземних партнерів, що забезпечує передумови для створення на базі газосховищ Східноєвропейського газового хабу. Однак, на перепоні вище зазначеному існує декілька важливих завдань: взаємоузгодженість між українськими та закордонними (європейськими) операторами ГТС; консолідація нормативноправових сторін спільного користування послугами хабу;

На разі, нормативно-правовий базис функціонування підземних сховищ забезпечує Закон «Про ринок природного газу», Закон України «Про ратифікацію Протоколу про приєднання України до Договору про заснування Енергетичного Співтовариства». Досвід європейських країн показує, що торгівля газовими ресурсами відбувається безпосередньо у великих транзитних вузлах (хабах), де зручно перерозподіляти постачання. Українська практика, на відміну від європейської для постачання палива використовує здебільшого підземні сховища, які є поруч з транзитними вузлами, тим самим зменшує витрати на транспортування хабу. Особливий комерційний інтерес виникає у міжнародних енергетичних компаній відносно реверсних поставок газу через Україну через близькість кордону з СС та перспективи збільшення активної місткості до 30 млрд м.куб.

Станом на сьогодні, Україна може запропонувати трейдерам можливість впливати на сезонні цінові коливання під час основної торгівлі газом Європи та передумовою входження України до європейського газового ринку. Залучення для роботи вітчизняних підземних сховищ європейських газотрейдерів за рахунок уніфікації європейського енергетичного законодавства через присутність на вітчизняному газовому ринку європейських газових компаній. Інтегрування вітчизняного газового ринку з конкурентними лібералізованими газовими ринками дозволить забезпечити рентабельність усіх транзитних газопроводів України з урахуванням навіть сценарію мінімального завантаження газотранспортної системи імпортними поставками російського газу. Задля реалізації моделі Східноєвропейського газового хабу слід розробити модель газового майданчика та дотичної транскордонної інфраструктури, з’ясувати джерела фінансування роботи хабу та законодавчодопустимого законодавства.

Наступним станом по створенню хабу має бути моніторинг по з'ясуванню ринкової кон'юнктури маркетингового середовища, з'ясування проблемних питань щодо створення та розвитку зазначеного органу. 
Висновки. Узагальнюючи сказаним, слід концептуалізувати послідовність заходів що передбачають: інтегрування бізнес-планів хабів до технічних умов бізнес-планів країн Європи; визначення найбільш оптимальних шляхів для України задля створення хабу; нормативно-методичне забезпечення; економіко-організаційна модель функціонування хабу; інформаційне та програмне забезпечення; комплексні гарантії щодо безпечності поставок іноземним власникам газу; адаптація діючого хабу до європейської мережі хабів.

На разі диверсифікація природнього газу в системі лібералізованих регіональних ринків сприятиме: підвищенню енергетичної безпеки України; стимулюванню якості та рівня стосунків між Україною та ЄС; Центральної та Східної Свропи; формуванню сприятливого мікроклімату.

\section{Джерела та література}

1. Дзюба О. Г. Управління трансформаціями та розвитком системи газозабезпечення: монографія. ІваноФранківськ. 2012. 352c.

2. Офіційний сайт національної комісії, що здійснює державне регулювання у сферах енергетики та комунальних послуг. URL: https://www.nerc.gov.ua/?id=11889 (дата звернення: 30.06.2019).

3. Павлов К.В. Застосування методів нормування показників та нечіткої логіки при оцінці рівня екологобезпечного природокористування. Структурні зміни в економічі природокористування: теоретичні основи та прикладні аспекти / за заг. Ред д-ра екон. наук, проф О.М. Стрішенець. Луцьк. 2016. С. 4663.

4. Павлов К.В., Федина К.М. Проблеми екологічної безпеки як складової частини енергетичної безпеки України. Актуальні проблеми прикладної економіки / за заг. ред. д-ра екон. наук, проф О.М. Стрішенець. Луцьк. 2017. С.85-98.

5. Павлов К.В. Сутність та загрози фінансово-економічній безпеці України. Проблеми раціонального використання соиіально-економічного та природно-ресурсного потениіалу регіону: фінансова політика та інвестииії. Збірник наукових праць. XX(2). Київ./Рівне. 2014. С.104-110.

6. Про покладення функцій оператора єдиної газотранспортної системи України. Наказ Міністерства енергетики та вугільної промисловості Украӥни. URL:https://zakon.rada.gov.ua/laws/show/z2075-13 (дата звернення: 30.06.2019).

7. Про реформування нафтогазового комплексу України. Указ президента Украӥни. 25 лютого 1998. URL: https://zakon.rada.gov.ua/laws/show/151/98 (дата звернення: 30.06.2019).

8. Про утворення Національної акціонерної компаніїі «Нафтогаз України». Постанова Кабінету Міністрів України. 25 травня 1998. 747. URL: https://zakon.rada.gov.ua/laws/show/747-98-\%D0\%BF (дата звернення: 30.06.2019).

9. Проміжна фінансові звітність ПАТ «Укртрансгаз» за 9 місяців 2018 року. URL: https://utg.ua/img/menu/company/reports/2018/fin-report-upto-25-10-2018.pdf (дата звернення: 30.06.2019).

10. Стрішенець О. М., Новосад О.В. Особливості функціонування інновацій в діяльності газорозподільчих підприємств. Актуальні проблеми управління соиіально-економічними системами: матеріали міжнародної науково-практичної інтернет-конференції. 07 грудня 2017. 1. Луцьк. 2017. С.162-163;

11.Стрішенець О.М. До питання про майбутнє теорії ринкового фундаменталізму. Науковий вісник. Серія: Економічні науки. Чернівці. 2012. 1. С.386-391.

\section{References}

1. Dzjuba O. Gh. (2012) Upravlinnja transformacijamy ta rozvytkom systemy ghazozabezpechennja: monoghrafija [Management of Transformations and Development of the Gas Supply System: Monograph]. Ivano-Frankivsk: IFNTUNH [in Ukrainian].

2. Oficijnyj sajt nacionaljnoji komisiji, shho zdijsnjuje derzhavne reghuljuvannja u sferakh energhetyky ta komunaljnykh poslugh [The official website of the National Commission, which carries out state regulation in the fields of energy and utilities] https://www.nerc.gov.ua/?id=11889. Retrieved from https://www.nerc.gov.ua/?id=11889 (accessed: 30 July 2019) [in Ukrainian];

3. Pavlov K.V., Strishenets O.M. (Eds.) (2016). Zastosuvannya metodiv normuvannya pokaznikiv ta nechitkoyi logiki pri otsintsi rivnya ekologo-bezpechnogo prirodokoristuvannya [Application of the methods of valuation of indicators and fuzzy logic in assessing the level of ecologically safe nature management]. Strukturni zmini $v$ ekonomitsi prirodokoristuvannya: teoretichni osnovi ta prikladni aspekti-Structural Changes in the Economics of Natural Resources: Theoretical Foundations and Applied Aspects. (pp. 46-63). Lutsk: VezhaDruk [in Ukrainian]. 
4. Pavlov K.V., Fedina K. M., Strishenets O.M. (Eds.) (2017). Problemi ekologichnoyi bezpeki yak skladovoyi chastini energetichnoyi bezpeki Ukrayini [Problems of ecological safety as an integral part of Ukraine's energy security]. Aktualni problemi prikladnoyi ekonomiki-Actual problems of applied economics. Lutsk : Vezha-Druk [in Ukrainian].

5. Pavlov K.V. (2014). Sutnist ta zagrozi finansovo-ekonomichniy bezpetsi Ukrayini [Essence and threats to financial and economic security of Ukraine]. Problemi ratsionalnogo vikoristannya sotsialno-ekonomichnogo ta prirodno-resursnogo potentsialu regionu: finansova politika ta Investitsiyi-Problems of rational use of socio-economic and natural-resource potential of the region: financial policy and investments. zb. nauk. prats - Collected papers (22, Vols. 2), (pp. 104-110). Kiyiv, SEU / Rivne, NUVGP [in Ukrainian].

6. Pro pokladennja funkcij operatora jedynoji ghazotransportnoji systemy Ukrajiny. Nakaz Ministerstva energhetyky ta vughiljnoji promyslovosti Ukrajiny pryjnjatyj 2 ghrudnja 2013 roku \# 882 [On the introduction of functions of the operator of the unified gas transportation system of Ukraine. Order of the Ministry of Energy and Coal Industry of Ukraine from December 2, 2013 No. 882] Retrieved from https://zakon.rada.gov.ua/laws/show/z2075-13 (accessed: 30 July 2019) [in Ukrainian];

7. Pro reformuvannja naftoghazovogho kompleksu Ukrajiny. Ukaz prezydenta Ukrajiny pryjnjatyj 25 ljutogho 1998 roku [On the reformation of the oil and gas complex of Ukraine. The decree of the President of Ukraine was adopted on February 25, 1998] Retrieved from https://zakon.rada.gov.ua/laws/show/151/98 (accessed: 30 July 2019) [in Ukrainian];

8. Pro utvorennja Nacionaljnoji akcionernoji kompanijiji « Naftoghaz Ukrajiny». Postanova Kabinetu Ministriv Ukrajiny pryjnjatyj 25 travnja 1998 roku \# 747 [On the formation of the National Joint-Stock Company Naftogaz of Ukraine. The Resolution of the Cabinet of Ministers of Ukraine was adopted on May 25, 1998, No. 747.] Retrieved from https://zakon.rada.gov.ua/laws/show/747-98-\%D0\%BF (accessed: 30 July 2019) [in Ukrainian];

9. Promizhna finansovi zvitnist' PAT «Ukrtrans·haz» za 9 misyatsiv 2018 roku [Interim financial statements of PJSC "Ukrtransgaz" for 9 months of 2018] https://utg.ua/img/menu/company/reports/2018/fin-report-upto-2510-2018.pdf. Retrieved from https://utg.ua/img/menu/company/reports/2018/fin-report-upto-25-10-2018.pdf (accessed: 30 July 2019) [in Ukrainian];

10. Strishenecj O. M., Novosad O. V. (2017) Osoblyvosti funkcionuvannja innovacij v dijaljnosti ghazorozpodiljchykh pidpryjemstv [Features of functioning of innovations in the activity of gas distributing enterprises]. Aktualjni problemy upravlinnja socialjno-ekonomichnymy systemamy: materialy mizhnarodnoji naukovo-praktychnoji internet-konferenciji., 07 ghrudnja 2017r, chastyna 1 - Actual problems of management of socio-economic systems: materials of the international scientific and practical Internet conference, 1 (pp. 162-163) - Lutsk: RWW Lutskoho NTU [in Ukrainian];

11. Strishenets O. M. (2012). Do pitannya pro maybutnE teoriyi rinkovogo fundamentalizmu [To the question of the future of the theory of market fundamentalism]. Naukoviy visnik. Seriya : Ekonomichni nauki / Bukovinskiy derzh. finans. un-t (1), (pp.386-391). Chernivtsi : Vid-vo BDFU [in Ukrainian].

Стаття надійшла до редакції 30.04.2019 р.

УДК 338.244.47

Хомюк Наталія, кандидат економічних наук, Східноєвропейський національний університет імені Лесі Українки, докторант кафедри міжнародних економічних відносин та управління проектами; м. Луцьк; ORCID ID 0000-0002-3277-8840 e-mail: nataljabilous@gmail.com

https://doi.org/10.29038/2411-4014-2019-03-112-120
МЕХАНІЗМ ДИВЕРСИФІКАЦІЇ РОЗВИТКУ СІЛЬСЬКИХ ТЕРИТОРІЙ В УМОВАХ ДЕЦЕНТРАЛІЗАЦІЇ 